\title{
Penerapan Fisika Komputasi dengan MATLAB/Simulink pada Pemodelan Infeksi Wabah COVID-19 di Indonesia melalui Modifikasi Persamaan Differensial Bernoulli
}

\author{
Valentinus Galih Putra ${ }^{(1, a)^{*}}$, Andrian Wijayono ${ }^{(2, b)}, \operatorname{Irwan}^{(2, \mathrm{c})}$, Juliany Ningsih \\ Mohamad $^{(3, \mathrm{~d})}$, Cahaya Rosyidin ${ }^{(4, \mathrm{e})}$ \\ ${ }^{1}$ Laboratorium Fisika Komputasi dan Mekatronika, Politeknik STTT Bandung, Jalan Jakarta No.31 Bandung, Jawa \\ Barat, Indonesia \\ ${ }^{2}$ BPSDMI, Kementerian Perindustrian RI, Jakarta, Indoensia \\ ${ }^{3}$ Jurusan Fisika, Universitas Nusa Cendana, Kupang, Nusa Tenggara Timor, Indonesia \\ ${ }^{4}$ Laboratorium Fisika, Teknik Perminyakan, Universitas Trisakti, jakarta, , Indonesia \\ Email: ${ }^{\left(a^{*}\right)}$ valentinus@kemenperin.go.id ${ }^{b)}$ wijayono@kemenperin.go.id; ${ }^{c}$ irwan@kemenperin.go.id; \\ d) ning_she@staf.undana.ac.id; ${ }^{e)}$ cahayarosyidan@trisakti.ac.id
}

Diterima ( 14 April 2020 ), Direvisi (07 Juli 2020)

\begin{abstract}
The application of physics, in particular, the topic of differential equations is commonly used in mathematics, physics, engineering, and various other sciences to explain a phenomenon in a system, to produce a form of simulation and prediction of a fairly good mathematical equation is needed. This paper examines the use of MATLAB / Simulink to assist in modeling the form of differential equation reports by providing examples of mathematical modeling in the analysis of the COVID-19 outbreak in Indonesia in 2020 with the conversion of the Bernoulli index. In this study, it can be concluded that MATLAB / Simulink can be used to solve differential equation reports with Bernoulli's modification in the example of COVID-19 plague modeling quite accurately.Based on this study, we found that $\mathrm{R}^{2}=0.9852$ on the total number of positive COVID-19 in Indonesia taken from 3 March 2020 to 12 April 2020, while the value of $R^{2}=0.7871$ daily number of new positive COVID-19 cases in Indonesia taken from 3 March 2020 to 12 April 2020.
\end{abstract}

Keywords: Bernoulli, COVID-19, Computational Physics, MATLAB.

\begin{abstract}
Abstrak. Penerapan fisika komputasi, khususnya topik persamaan differensial biasa pada saat ini diperlukan untuk membantu dalam penyelesaian beberapa kasus rumit dalam fisika matematik lanjut. Penerapan persamaan differensial biasanya digunakan pada ilmu matematika, ilmu fisika, teknik dan berbagai ilmu lain untuk menjelaskan suatu fenomena pada sebuah sistem, sehingga suatu bentuk simulasi dan prediksi dari sebuah persamaan matematik yang cukup baik sangatlah diperlukan. Paper ini mengkaji penggunaan MATLAB/ Simulink untuk membantu dalam pemodelan bentuk kasus persamaan differensial biasa dengan memberikan contoh pemodelan matematik pada analisa wabah COVID-19 di Indonesia pada tahun 2020 dengan modifikasi persamaan Bernoulli. Pada penelitian ini dapat disimpulkan bahwa MATLAB/Simulink dapat digunakan untuk menyelesaikan kasus persamaan differensial dengan modifikasi persamaan Bernoulli pada contoh pemodelan wabah COVID-19 dengan cukup akurat, yaitu $\mathrm{R}^{2}=0.9852$ pada jumlah total positif COVID-19 di Indonesia yang diambil dari 3 Maret 2020 hingga 12 April 2020, sedangkan nilai $\mathrm{R}^{2}=0.7871$ jumlah harian kasus baru positif COVID-19 di Indonesia yang diambil dari 3 Maret 2020 hingga 12 April 2020.
\end{abstract}

Kata kunci: Bernoulli, COVID-19, MATLAB, Fisika komputasi. 


\section{PENDAHULUAN}

Persamaan differensial biasa atau (ordinary differential equation) biasanya digunakan pada ilmu matematika, ilmu fisika, teknik dan berbagai ilmu lain untuk menjelaskan suatu fenomena pada sebuah sistem [1-17]. Pada ilmu fisika-teori topik tentang persamaan differensial umum dapat ditemui di berbagai bidang kajian dari fisika komputasi, fisika bumi, fisika zat padat, fisika medis, fisika komputasi dan sebagainya. Persamaan differensial umum adalah suatu persamaan yangmana terdapat suatu variabel bebas, sebagai contoh waktu $(t)$ dan terdapat satu atau lebih suatu derivative sebagai suatu fungsi dari variabel bebas, sebagai contoh suatu derivative $I(t)=\frac{d I(t)}{d t}$. Pada sebuah pemodelan dengan persamaan differensial umum nilai variabel $I(t)$ sangatlah penting untuk didapatkan. Hasil nilai $I(t)$ umumnya dapat digunakan untuk menjelaskan fenomena pada beberapa kasus [1]. Persamaan differensial umum dapat ditemui dalam banyak bidang ilmu fisika, seperti geometri, mekanika, astronomi, fisika partikel, fisika medis, fisika tekstil, fisika material dan sebagainya para peneliti seperti [1-7]. Penerapan model dengan menggunakan sistem persamaan differensial pada bidang tekstil salah satunya dilakukan oleh beberapa peneliti seperti $[8,9]$. Penerapan persamaan differensial umum dalam bidang medis salah satunya adalah pemodelan untuk menganalisa suatu penyebaran infeksi wabah. Beberapa bentuk persamaan differensial umum dalam menganalisa penyebaran suatu wabah dapat diperlihatkan pada Persamaan (1), Persamaan (2) dan Persamaan (3) di bawah [7]

$$
\frac{d S}{d t}=\mu\left(S^{0}-S\right)-\lambda S
$$

$$
\begin{gathered}
\frac{d I}{d t}=\lambda S-(\mu+\gamma+\delta) I \\
\frac{d R}{d t}=\gamma I-(\mu+\xi) R
\end{gathered}
$$

Dengan parameter $S, I, R$ adalah individu yang rentan (Susceptible) terkena wabah, individu yang terinfeksi (infected) dan individu yang mengalami pemulihan (recovered) . Nilai $\mu, \gamma, \delta, \xi, \lambda$ adalah konstanta-konstanta yang mempengaruhi laju parameter $S, I, R$. Beberapa peneliti seperti [1-3,5-7] menggunakan pemodelan SIR yaitu dengan bentuk model secara umum adalah seperti pada Persamaan (4), Persamaan (5) dan Persamaan (6)

$$
\begin{gathered}
\frac{d S}{d t}=-\alpha S I \\
\frac{d I}{d t}=\alpha S I-\beta I \\
\frac{d R}{d t}=\beta I
\end{gathered}
$$

Dengan parameter $S, I, R$ adalah individu yang rentan (Susceptible) terkena wabah, individu yang terinfeksi (infected) dan individu yang mengalami pemulihan (recovered) . Nilai $\alpha, \beta$ adalah konstantakonstanta yang mempengaruhi laju parameter $S, I, R$. Para peneliti memodelkan bentuk persamaan SIR untuk menjelaskan titik optimum penyebaran infeksi wabah, prediksi wabah berakhir dan juga menentukan jumlah individu yang rentan terinfeksi wabah. Bentuk pemodelan mengenai wabah suatu virus khususnya COVID-19 juga telah dikembangkan oleh 
Nuraini, Khairudin, Apri [6] menggunakan model pengembangan Logistik Kurva Richard seperti pada Persamaan (7)

$$
\begin{aligned}
& \frac{d y(t)}{d t} \\
& =\frac{r}{\alpha} y\left(1-\left(\frac{y}{K}\right)^{\alpha}\right) \text { dan } y(t) \\
& =\frac{K}{\left(1+\alpha e^{(-r \Delta t}\right)^{1 / a}}
\end{aligned}
$$

Dengan $y(t)$ adalah kasus kumulatif terkontaminasi, $K$ maksimum kasus terkonfirmasi prediksi, $\alpha, r$ adalah koefisien fitting data, $\Delta t$ adalah selisih lama hari sejak pertama kali kasus. Hasil pemodelan Nuraini, Khairudin, Apri, [6] menggunakan bentuk persamaan model logistik. Model logistic umumnya digunakan dalam kasus untuk memprediksi suatu epidemiologi. Model ini biasanya digunakan untuk menganalisa faktor resiko pada suatu wabah dan memprediksi kemungkinan kejadian pada suatu wabah berdasarkan faktor resiko. Suatu kasus pneumonia akut yang disebabkan virus COVID-19 di China juga telah diteliti oleh Lin Jia, Kewen Li, Yu Jiang, Xin Guo \& Ting zhao [10] dengan menggunakan pemodelan melalui penggabungan beberapa meodel seperti model logistic, model Bertalanffy dan juga model Gompertz, hasil prediksi pada model tersebut cukup akurat untuk memprediksi penyebaran wabah COVID-19 di Wuhan, China. Beberapa pemodelan mengenai wabah suatu virus juga telah dilakukan oleh beberapa peneliti [10-17]. Beberapa peneliti seperti Lipsitch M, Finelli L, Heffernan RT, Leung GM, Redd SC [14], Eubank S, Guclu H, Kumar VSA, Marathe M, Srinivasan A, et al. [15], Wallinga J, Teunis P [16], Barrett C, Bisset K, Leidig J, Marathe A, Marathe M [17] Grassly N C [3], Keeling M J,Rohani P [11], Yuan D F, Ying L Y, Dong C Z [12],Zhang F, Li L, Xuan H Y. [13], Lipsitch M, Finelli L, Heffernan RT, Leung
GM, Redd SC [14] ,Lin Jia, Kewen Li, Yu Jiang, Xin Guo \& Ting zhao [10] yaitu seperti model-model berikut: Model Logistik adalah suatu model yang digunakan dalam epidemiologi dan digunakan untuk menganalisa faktor resiko. Bentuk pemodelan Logistik adalah, seperti Persamaan (8)

$$
Q(t)=\frac{a}{1+e^{(b-c)(\Delta t)}}
$$

Dengan $Q(t)$ adalah kasus kumulatif terkontaminasi, a maksimum kasus terkonfirmasi prediksi, b,c adalah koefisien fitting data, $\Delta t$ adalah selisih lama hari sejak pertama kali kasus. Model Bertalanffy adalah sebuah model yang biasa digunakan untuk menganalisa besar pertambahan suatu wabah infeksi virus dan juga pertumbuhan sebuah populasi. Perkembangan infeksi wabah mirip dengan pertumbuhan populasi dan individu. Model bertalanffy biasanya juga digunakan untuk memodelkan penyebaran infeksi virus. Bentuk pemodelan Bertalanffy dapat diperlihatkan seperti pada Persamaan (9)

$$
Q(t)=a\left(1-e^{-b(\Delta t)}\right)^{c}
$$

Dengan $Q(t)$ adalah kasus kumulatif terkontaminasi, a maksimum kasus terkonfirmasi prediksi, b,c adalah koefisien fitting data, $\Delta t$ adalah selisih lama hari sejak pertama kali kasus. Model Gomperts adalah sebuah model yang digunakan untuk memprediksi populasi perkembanga suatu hewan. Model ini dapat digunakan untuk menjelaskan penyebaran infeksi suatu wabah dan mempelajari faktor yang mengkontrol dan mempengaruhi penyebaran suatu infeksi wabah. Bentuk model ini dapat dieprlihatkan pada Persamaan (10)

$$
Q(t)=a e^{-b e^{-c(\Delta t)}}
$$

Dengan $Q(t)$ adalah kasus kumulatif terkontaminasi, a maksimum kasus terkonfirmasi prediksi, b,c adalah koefisien 
Valenyinus, dkk : Penerapan Fisika Komputasi dengan MATLAB/Simulink pada Pemodelan Infeksi Wabah COVID-19 di Indonesia melalui Modifikasi Persamaan Differensial Bernoulli

fitting data, $\Delta t$ adalah selisih lama hari sejak pertama kali kasus. Pada pemodelan kasus COVID-19 di Indoensia, hasil pemodelan Nuraini, Khairudin, Apri, [6] menggunakan bentuk persamaan modifikasi model logistic untuk dapat memprediksi proyeksi jumlah kasus COVID-19 di Indonesia dan jumlah kasus baru COVID-19 di Indonesia dengan mengikuti kurva model prediksi di Korea Selatan. Hasil pemodelan dapat diperlihatkan pada Gambar 1. Hasil pemodelan Nuraini, Khairudin, Apri, [6] memperlihatkan bahwa mulai epidemi COVID-19 di Indonesia berada di awal Maret 2020 dan puncak epidemic di akhir Maret 2020 dan akan berakhir apda pertengahan April 2020 dengan jumlah kasus maksimal 8000 kasus dan pertambahan jumlah kasus tiap ahri berada pada 600 di akhir Maret.

Pada penelitian ini dikaji suatu pola penyebaran kasus COVID-19 di Indonesia dengan menerapkan penerapan fisika komputasi menggunakan MATLAB/ Simulink dalam menganalisa dan menyelesaikan pemodelan infeksi wabah COVID-19 dengan menggunakan modifikasi persamaan Bernoulli yang lebih umum dari model Nuning dkk [6] seperti pada Persamaan (11)

$$
\frac{d I}{d t}+p I=q I^{n}
$$

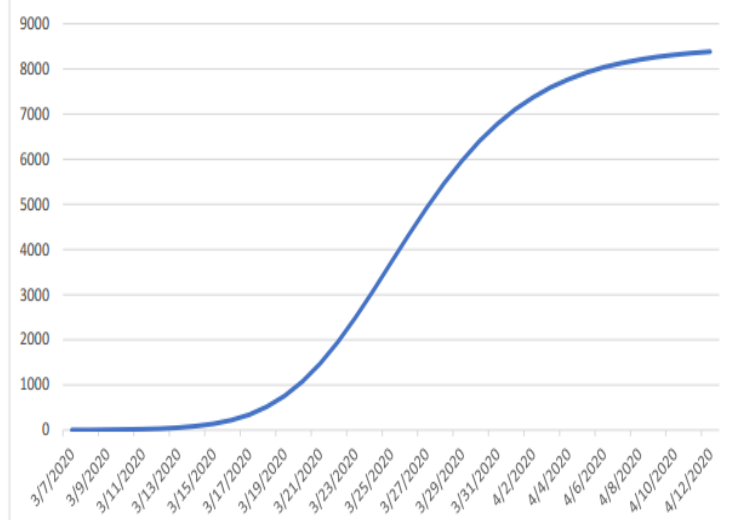

(a)

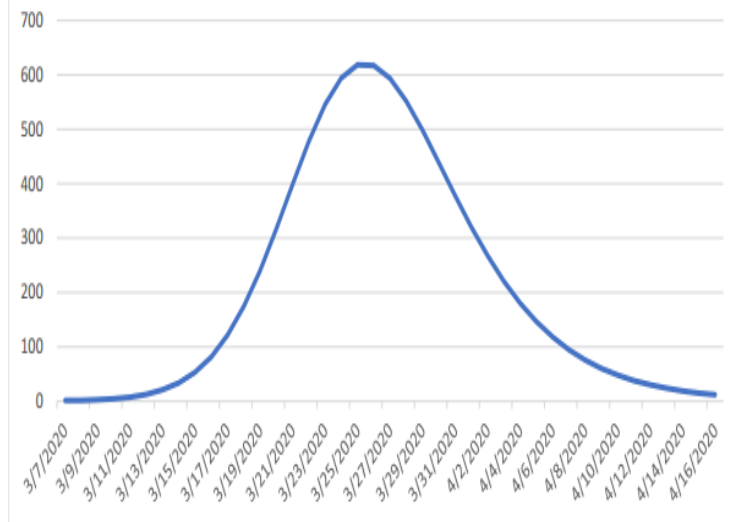

(b)

Gambar 1. a) proyeksi jumlah kasus COVID-19 di Indonesia; b) jumlah kasus baru COVID-19 di Indonesia (Nuning Nuraini, Kamal Khairudin S, Mochamad Apri [6]

\section{METODE PENELITIAN}

Pada pemodelan ini digunakan model persamaan Bernoulli dalam memprediksi kasus COVID-19 di Indonesia. Data kasus diambil dari tanggal 3 Maret 2020 hingga 12 April 2020. Data yang diambil adalah data jumlah total pasien yang terinfeksi COVID19 dan juga laju pertambahan pasien
COVID-19 tiap hari. Batasan pada pemodelan ini adalah situasi yang diterapkan di Indonesia adalah social distancing ketat dan masyarakat menyadari dengan sungguh pentingnya social distancing tersebut serta tidak terdapat perpindahan orang dari luar negeri ke dalam negeri dalam skala besar. Pada model Bernoulli seperti pada Persamaan (11) dapat diselesaikan dengan cara berikut: Dimisalkan bahwa $I=y^{1-n}$, maka akan didapatkan differensial sekali 
terhadap waktu adalah seperti Persamaan (12)

$$
\frac{d I}{d t}=(1-n) y^{-n} y^{\prime}
$$

Kalikan kedua ruas pada Persamaan (11) dengan $(1-n) y^{-n} y^{\prime}$ maka didapatkan Persamaan (13)

$$
\begin{aligned}
(1-n) y^{-n} y^{\prime}+ & (1-n) y^{-n} p y \\
& =q(1-n) y^{n} y^{-n}
\end{aligned}
$$

Substitusikan Persamaan (12) ke Persamaan (13.a), sehingga didapatkan Persamaan (13.b) dan persamaan (13.c)

$$
\begin{aligned}
\frac{d I}{d t}+(1-n) p I & =(1-n) q \\
\frac{d I}{d t}+G I & =N
\end{aligned}
$$

Hasil penyelesaian persamaan (13.c) dapat dijabarkan sebagai berikut Persamaan (14)

$$
(D+G) I=N
$$

Dapat dimisalkan nilai $\mathrm{N}=0$, sehingga didapatkan Persamaan (15) dan Persamaan (16)

$$
\begin{aligned}
& (D+G) I=0 \\
I= & A \exp \left(-\int G d t\right) \\
= & A \exp (-G t)
\end{aligned}
$$

Substitusikan Persamaan (16) ke Persamaan (14) maka didapatkan Persamaan (20)

$$
\begin{aligned}
& \frac{d A \exp (-G t)}{d t} \\
& +G A \exp (-G t)=N
\end{aligned}
$$

$$
\begin{aligned}
& A \frac{\operatorname{dexp}(-G t)}{d t} \\
& +\exp (-G t) \frac{d A}{d t} \\
& +G A \exp (-G t)=N
\end{aligned}
$$

$-A G \exp (-G t)$

$+\exp (-G t) \frac{d A}{d t}$

$+G A \exp (-G t)=N$

$$
\exp (-G t) \frac{d A}{d t}=N
$$

Sehingga didapatkan persamaan (21)

$$
A=\int N \exp (G t) d t
$$

Dengan nilai $I(t)$ adalah sesuai Persamaan (22)

$$
\begin{aligned}
I(t)=\left[\int N \exp (G t)\right. & d t+C] \exp (-G t) \\
= & {\left[\int((1\right.} \\
& -n) q) \exp ([(1-n) p] t) d t \\
& +C] \exp (-[(1-n) p] t)
\end{aligned}
$$

Dalam melakukann pemodelan wabah dapat dilakukan modifikasi Persamaan (11) sebagai berikut (dapat dilihat pada persamaan (23) hingga Persamaan (26))

$$
\begin{gathered}
\frac{d I}{d t}+p I=q I^{n} \\
\frac{d I}{d t}=p I-q I^{n}=p\left(I-\frac{q}{p} I^{n}\right)
\end{gathered}
$$


Valenyinus, dkk : Penerapan Fisika Komputasi dengan MATLAB/Simulink pada Pemodelan Infeksi Wabah COVID-19 di Indonesia melalui Modifikasi Persamaan Differensial Bernoulli

Jika $n=1+m$, maka

$$
\begin{aligned}
\frac{d I}{d t}=p\left(I-\frac{q}{p} I^{(1+m)}\right) & \\
=p\left(I-\frac{q}{p} I^{(1+m)}\right) & (t)=\left[\int\left(m \frac{r}{\Omega \theta^{m}}\right) \exp \left(m \frac{r}{\Omega} t\right) d t\right. \\
=p I\left(1-\frac{q}{p} I^{m}\right) & +C] \exp \left(-m \frac{r}{\Omega} t\right)
\end{aligned}
$$

a $p=\alpha=\frac{r}{\Omega}$ dan $q=\beta p$ dan $\frac{1}{\theta^{m}}=\beta$

$$
\begin{aligned}
\frac{d I}{d t}=\alpha I\left(1-\beta I^{m}\right) & \\
& =\frac{r}{\Omega} I(1 \\
& \left.-\left(\frac{I}{\theta}\right)^{m}\right)
\end{aligned}
$$

Persamaan (26) memiliki penyelesaian yaitu Persamaan (27)

Dengan $r, \Omega, \theta$ dan $m$ adalah konstanta fitting yang akan disesuaikan dengan data real jumlah kasus COVID-19 di Indonesia dan jumlah kasus baru COVID-19 di Indonesia. Pemodelan infeksi wabah total dan laju per hari dapat diselesaikan dengan menggunakan MATLAB/Simulink pada Persamaan (26) dengan model seperti pada

$$
\begin{gathered}
I(t)=\left[\int((1-n) q) \exp ([(1-n) p] t) d t\right. \\
+C] \exp (-[(1-n) p] t) \\
=\left[\int(m \beta \alpha) \exp (m \alpha t) d t\right. \\
+C] \exp (-m \alpha t)
\end{gathered}
$$

\section{Gambar 2}

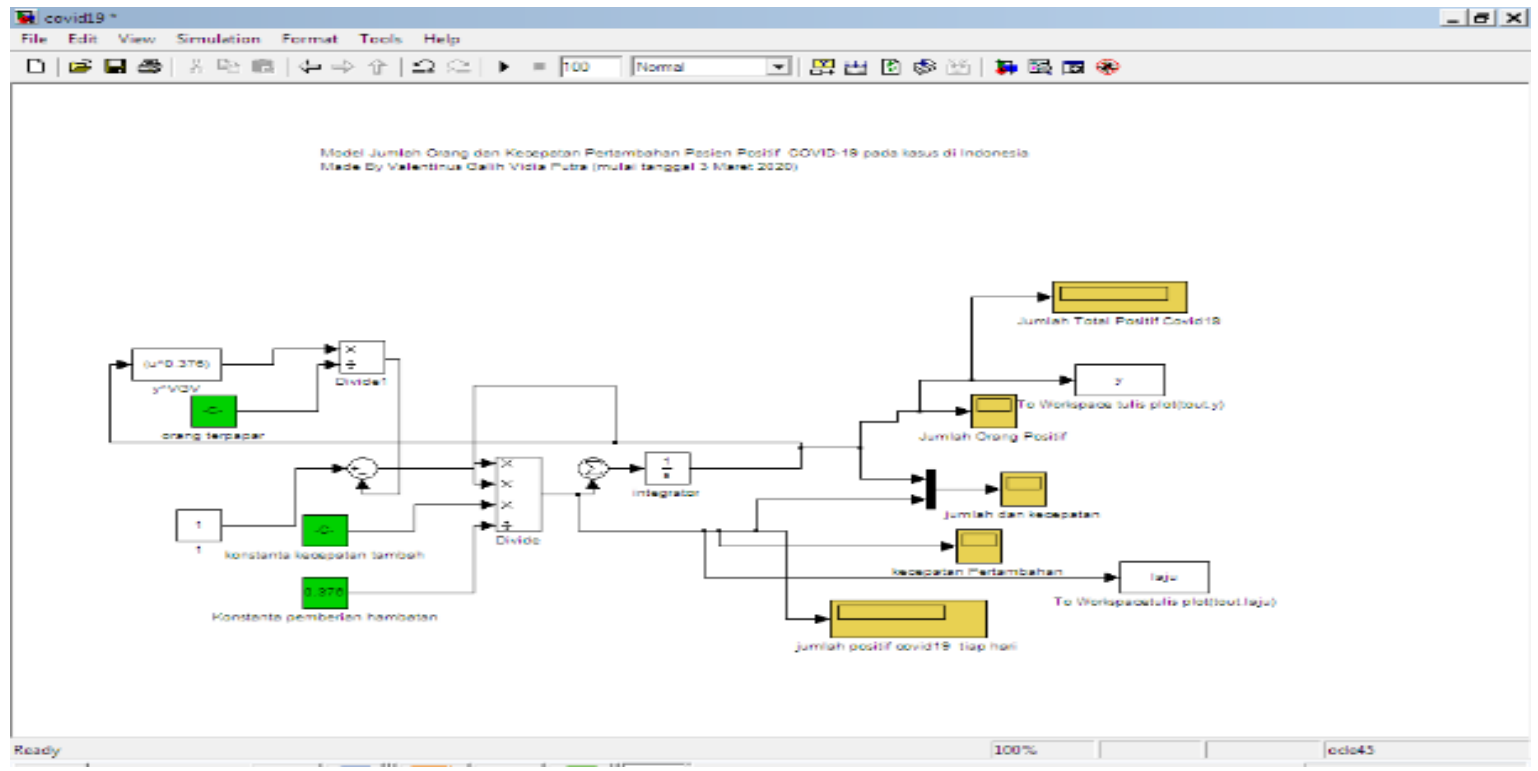

Gambar 2. Pemodelan MATLAB/Simulink Persamaan (26) 
Hasil Pemodelan dapat diperlihatkan sebagai berikut (Gambar 3 dan Gambar 4) dengan mengisi nilai-nilai konstanta dan melakukan perhitungan komputasi dan simulasi, maka didapatkan. Kurva prediksi jumlah harian kasus baru COVID-19 dan total jumlah kasus COVID-19 di Indonesia.

Berdasarkan hasil pemodelan dan dengan data real yang diambil dari 3 Maret 2020 hingga 12 April 2020, maka dapat dianalisa kesesuaian model dengan data real tersebut [18] seperti pada Gambar 5 dan Gambar 6 jumlah harian kasus baru dan total positif COVID-19 di Indonesia.

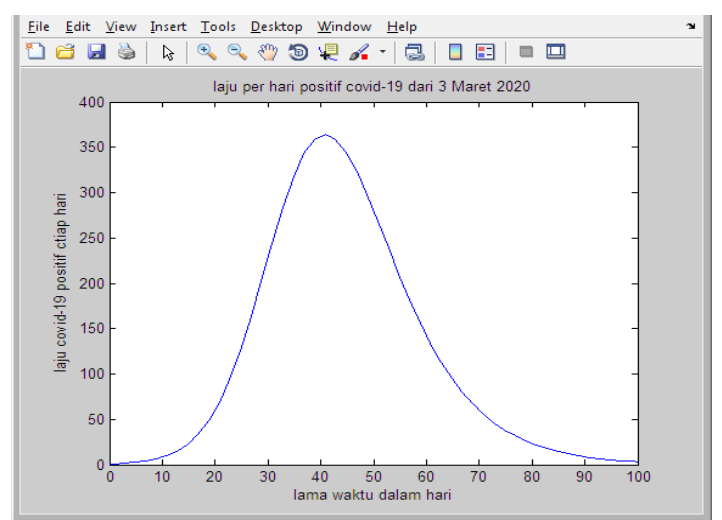

Gambar 3. jumlah harian kasus baru COVID-19 di Indonesia

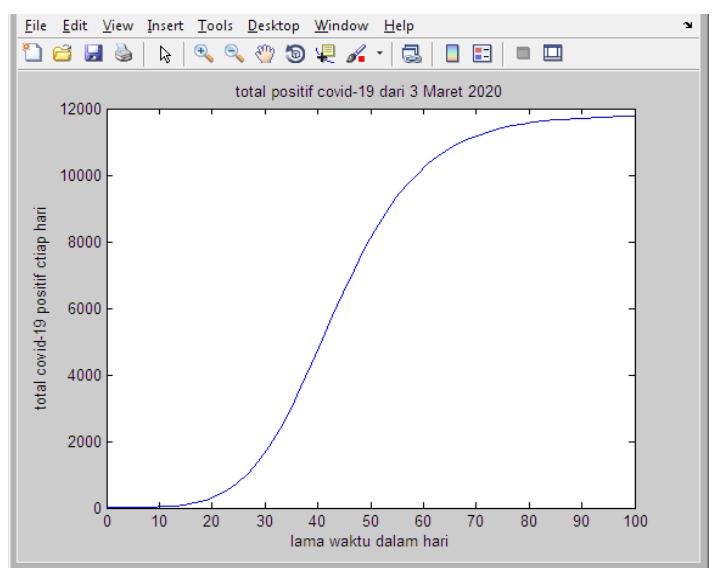

Gambar 4. Jumlah kasus total COVID-19 di Indonesia

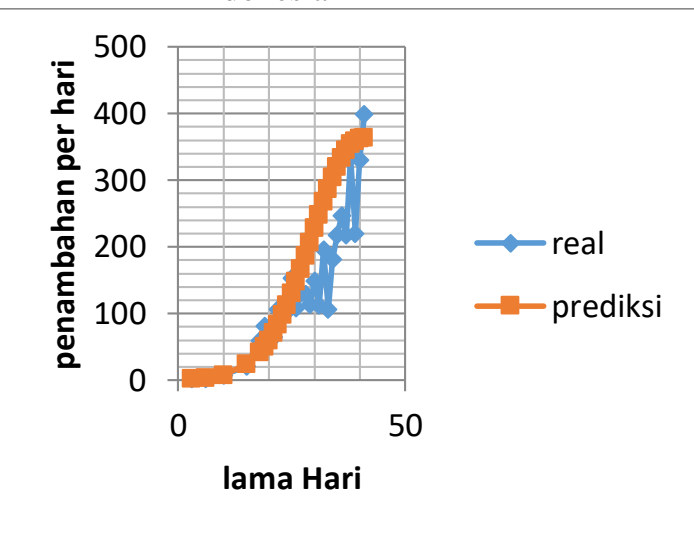

Gambar 5. Jumlah harian kasus baru COVID-19 di Indonesia real data dan prediksi

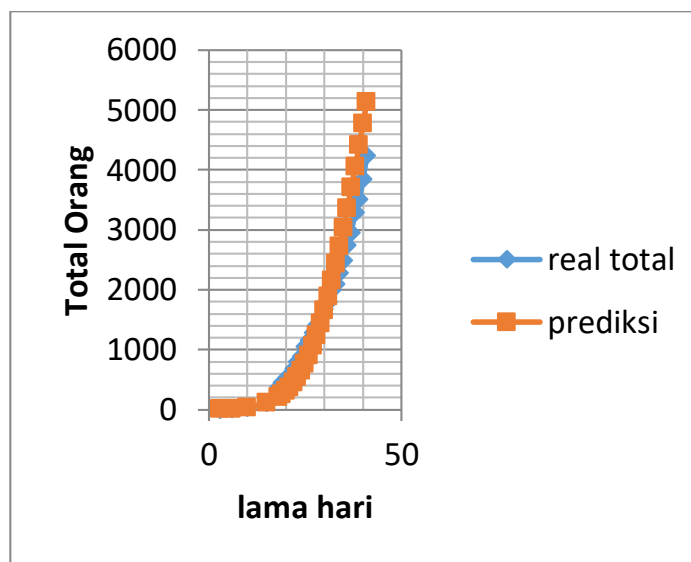

Gambar 6. Jumlah Total kasus positif COVID-19 di Indonesia Prediksi dan Real data

Dapat diperlihatkan pada Tabel 1. di bawah mengenai data real dan prediksi beserta nilai $R^{2}$ jumlah harian kasus baru dan total positif COVID-19 di Indonesia yang diambil dari 3 Maret 2020 hingga 12 April 2020. 
Valenyinus, dkk : Penerapan Fisika Komputasi dengan MATLAB/Simulink pada Pemodelan Infeksi Wabah COVID-19 di Indonesia melalui Modifikasi Persamaan Differensial Bernoulli

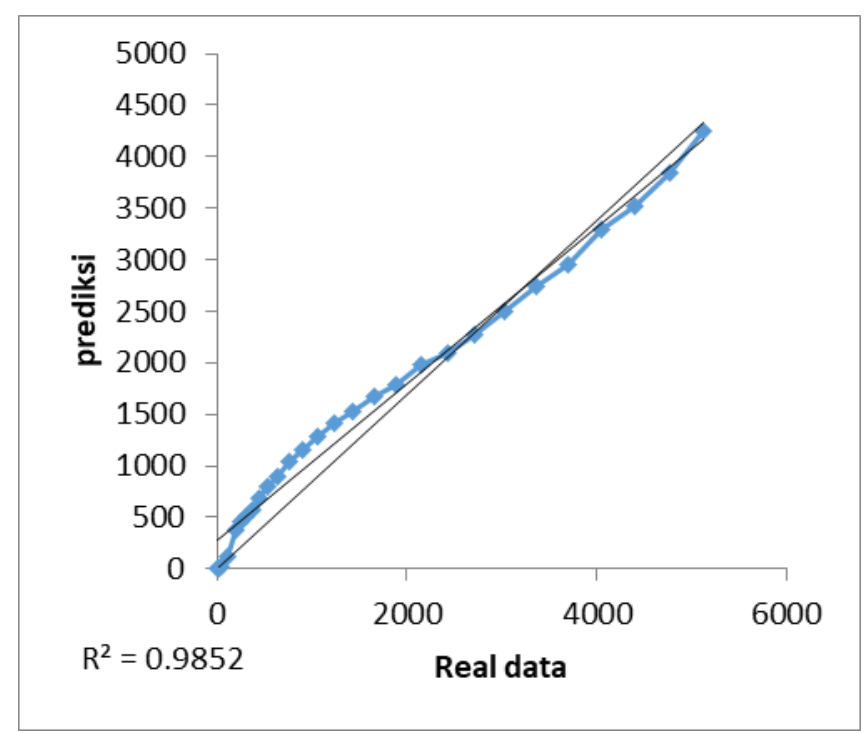

Gambar 7. nilai $\mathrm{R}^{2}$ Jumlah total positif COVID-19 di Indonesia yang diambil dari 3 Maret 2020 hingga 12 April 2020

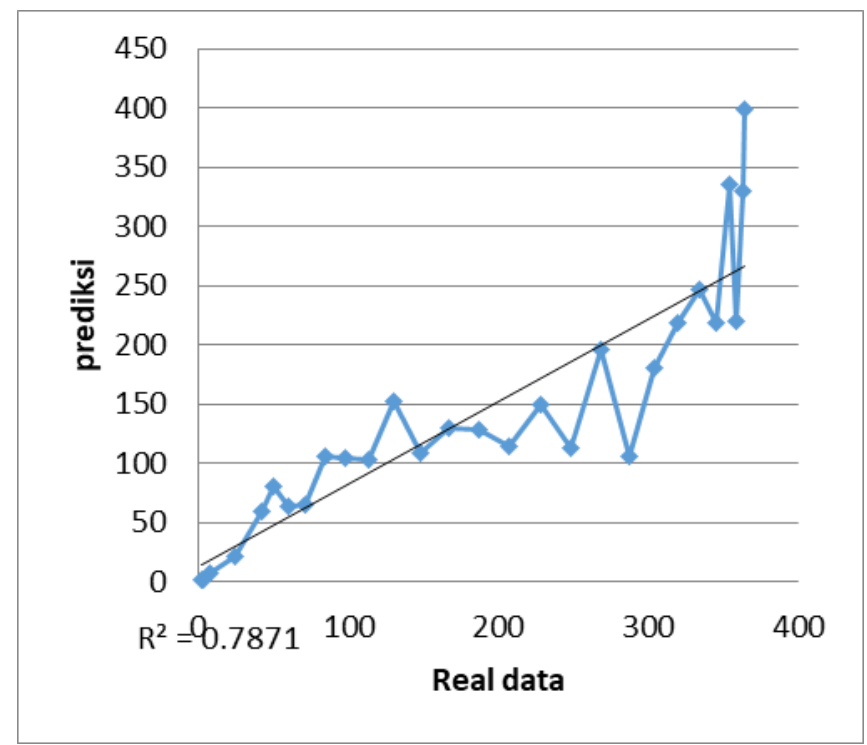

Gambar 8. Nilai $\mathrm{R}^{2}$ jumlah harian kasus baru positif COVID-19 di Indonesia yang diambil dari 3 Maret 2020 hingga 12 April 2020 
Tabel 1. Data real dan prediksi beserta nilai $R^{2}$ jumlah harian kasus baru dan total positif COVID-19 [18]

\begin{tabular}{|c|c|c|c|c|}
\hline $\begin{array}{c}\text { Lama hari } \\
\text { per } \\
3 \text { Maret } 2020\end{array}$ & $\begin{array}{c}\text { Jumlah } \\
\text { total real } \\
\text { positif } \\
\text { COVID-19 } \\
\end{array}$ & $\begin{array}{c}\text { Pertambahan per } \\
\text { hari real }\end{array}$ & $\begin{array}{c}\text { Pertambahan } \\
\text { prediksi } \\
\text { per hari }\end{array}$ & $\begin{array}{c}\text { Jumlah } \\
\text { Total } \\
\text { Positif } \\
\text { COVID19 } \\
\text { Prediksi } \\
\end{array}$ \\
\hline 3 & 2 & 2 & 2 & 6 \\
\hline 6 & 4 & 2 & 3 & 13 \\
\hline 10 & 27 & 8 & 8 & 35 \\
\hline 15 & 117 & 21 & 24 & 108 \\
\hline 18 & 369 & 60 & 42 & 203 \\
\hline 19 & 450 & 81 & 50 & 250 \\
\hline 20 & 514 & 64 & 60 & 305 \\
\hline 21 & 579 & 65 & 71 & 371 \\
\hline 22 & 685 & 106 & 84 & 448 \\
\hline 23 & 790 & 105 & 98 & 538 \\
\hline 24 & 893 & 103 & 113 & 643 \\
\hline 25 & 1046 & 153 & 130 & 764 \\
\hline 26 & 1155 & 109 & 148 & 903 \\
\hline 27 & 1285 & 130 & 167 & 1060 \\
\hline 28 & 1414 & 129 & 187 & 1237 \\
\hline 29 & 1528 & 114 & 207 & 1433 \\
\hline 30 & 1677 & 149 & 228 & 1651 \\
\hline 31 & 1790 & 113 & 248 & 1884 \\
\hline 32 & 1986 & 196 & 268 & 2147 \\
\hline 33 & 2092 & 106 & 287 & 2424 \\
\hline 34 & 2273 & 181 & 304 & 2720 \\
\hline 35 & 2491 & 218 & 320 & 3032 \\
\hline 36 & 2738 & 247 & 334 & 3359 \\
\hline 37 & 2956 & 218 & 345 & 3699 \\
\hline 38 & 3292 & 336 & 354 & 4048 \\
\hline 39 & 3512 & 220 & 359 & 4405 \\
\hline 40 & 3842 & 330 & 363 & 4767 \\
\hline 41 & 4241 & 399 & 364 & 5131 \\
\hline \multicolumn{5}{|c|}{$\mathrm{R}^{2}$ untuk Total kasus 0.9617} \\
\hline \multicolumn{5}{|c|}{$\mathrm{R}^{2}$ untuk laju kasus per hari 0.7817} \\
\hline
\end{tabular}




\section{HASIL DAN PEMBAHASAN}

Pada pemodelan ini telah dijabarkan model modifikasi persamaan Bernoulli dalam memprediksi kasus COVID-19 di Indonesia. Data kasus diambil dari tanggal 3 Maret 2020 hingga 12 April 2020. Data yang diambil adalah data jumlah total pasien yang terinfeksi COVID-19 dan juga laju pertambahan pasien COVID-19 tiap hari. Dari ahsil persamaan didapatkan bahwa model modifikasi persamaan Bernoulli dapat digunakan untuk memprediksi jumlah harian kasus baru dan total positif COVID19 di Indonesia. Hasil pemodelan yang digunakan pada persamaan ini yaitu seperti pada Persamaan (28)

$$
\begin{aligned}
\frac{d I}{d t}=\alpha I\left(1-\beta I^{m}\right) & \\
& =\frac{r}{\Omega} I(1 \\
& \left.-\left(\frac{I}{\theta}\right)^{m}\right)
\end{aligned}
$$

Dengan hasil penyelesaian yaitu seperti Persamaan (29)

$$
\begin{aligned}
& I(t) \\
& =\left[\int\left(m \frac{r}{\Omega \theta^{m}}\right) \exp \left(m \frac{r}{\Omega} t\right) d t\right. \\
& +C] \exp \left(-m \frac{r}{\Omega} t\right)
\end{aligned}
$$

Untuk nilai $\Omega=\mathrm{m}$, maka bentuk Persamaan (28) akan memiliki bentuk yang hampir mirip dengan model wabah suatu virus COVID-19 yang juga telah dikembangkan oleh Nuraini, Khairudin, Apri [6] dengan menggunakan model pengembangan Logistik Kurva Richard seperti pada Persamaan (7), sehingga bentuk Persamaan (28) dapat dimodifikasi menjadi Persamaan (30) di bawah

$$
\frac{d I(t)}{d t}=\frac{r}{\Omega} y\left(1-\left(\frac{y}{\theta}\right)^{\Omega}\right)
$$

Dengan $\Omega, r$ dan $\theta$ adalah konstanta fitting. Melalui pemodelan menggunakan MATLAB/Simulink, maka didapatkan bahwa jumlah harian kasus COVID-19 di Indonesia akan memiliki kasus tertinggi di maksimal 400 dan jumlah total positif COVID-19 di Indonesia akan mencapai 12000 orang dengan masa reda berada di pertengahan Juni. Pada pemodelan ini juga telah didapatkan bahwa besar nilai $\mathrm{R}^{2}$ $=0.9852$ pada jumlah total positif COVID19 di Indonesia yang diambil dari 3 Maret 2020 hingga 12 April 2020, sedangkan nilai $\mathrm{R}^{2}=0.7871$ jumlah harian kasus baru positif COVID-19 di Indonesia yang diambil dari 3 Maret 2020 hingga 12 April 2020. Berdasarkan kajian, maka situasi yang diterapkan di Indonesia dengan social distancing ketat dan adanya kesadaran masyarakat dengan sungguh mengenai pentingnya social distancing dan serta tidak terdapat perpindahan orang dari luar negeri ke dalam negeri dalam skala besar akan meredakan wabah COVID-19 ini pada pertengahan bulan Juni pertengahan. Pada penelitian ini juga telah didapatkan bahwa MATLAB/Simulink pada Gambar 2 dapat digunakan untuk menyelesaikan kasus persamaan differensial dengan persamaan Bernoulli pada contoh pemodelan wabah COVID-19 dengan cukup akurat. nilai-nilai parameter $r, \Omega$ dan $\theta$ menentukan bentuk kurva. Pada kasus ini didapatkan bahwa nilai $\mathrm{r}=0.0992, \Omega=0.376$ dan $\theta=12000$. Model ini berlaku untuk kondisi pada 3 Maret 2020 hingga 12 April 2020 tanpa ada perubahan gangguan pada model. 


\section{KESIMPULAN}

Telah dikaji penggunaan MATLAB/ Simulink untuk membantu penyelesaian kasus persamaan differensial biasa dengan memberikan contoh pemodelan matematik pada analisa wabah COVID-19 di Indonesia pada tahun 2020 dengan modifikasi persamaan Bernoulli. Pada penelitian ini dapat disimpulkan bahwa MATLAB/ Simulink dapat digunakan untuk menyelesaikan kasus persamaan differensial dengan persamaan Bernoulli pada contoh pemodelan wabah COVID-19 dengan cukup akurat

\section{UCAPAN TERIMA KASIH}

Penulis mengucapkan terima kasih kepada jurusan Teknik Tekstil Politeknik STTT Bandung, Jurusan Fisika Universitas trisakti dan Universitas Nusa Cendana yang telah mendukung kegiatan penelitian ini sehingga penelitian ini dapat diselesaiakan dengan baik.

\section{DAFTAR PUSTAKA}

[1] Blanchard, P. Robert, L.D., \& Glen,R.H. Ordinary differential Equations, Richard Stratton, 2012.

[2] Brooks Pollock, Ellen \& Eames, Ken T.D..Pigs didn't fly, but swine flu:, Mathematics Today, vol.47,Hal..3640. 2011.

[3] N C Grassly, C. Fraser, Mathematical models of infectious disease transmission. Nature Reviews Microbiology,6(6):477-487, 2008.

[4] L. Stone, B. Shulgin, Z.Agur, Theoretical Examination of the Pulse Vaccination Policy in the SIR
Epidemic Model, Proceedings of the Conference on Dynamical Systems in Biology and Medicine), Math. Comput. Modelling , Vol. 31, No.4-5, 207-215, 2000.

[5] F. A. Rihan, \& N. M. Anwar, Qualitative analysis of delayed SIR epidemic model with a saturated incidence rate, International Journal of Differential Equations, Art. pp. ID 408637, 13, 2012.

[6] N. Nuraini, K. Khairudin,M Apri, Data dan Simulasi COVID-19 dipandang dari Pendekatan Model Matematika, Bandung: Institut Teknologi Bandung, 2020.

[7] M. James Hyman \&Jia Li, Differential susceptibility epidemic models, $J$. Math. Biol. 50, 626-644, 2005.

[8] VGV Putra., G. Maruto \& M.F Rosyid, New theoretical modeling for predicting yarn angle on $\mathrm{OE}$ yarn influenced by fibre movement on torus coordinate based on classical mechanics approach, Indian Journal of Fibre and Textile Research, Vol.42, pp. 359-363, 2017.

[9] VGV Putra, M.F. Rosyid, \& G.Maruto, ,A Simulation Model of Twist Influenced by Fibre Movement Inside Yarn on Solenoid Coordinate, Global Journal of Pure and Applied Mathematics, Vol 12.,No.1, pp. 405412, 2016.

[10] Lin Jia, Kewen Li, Yu Jiang, Xin Guo \& Ting Zhao, Prediction and analysis of Corona virus Disease 2019, Beijing: China university of Geosciences, 2020. 
Valenyinus, dkk : Penerapan Fisika Komputasi dengan MATLAB/Simulink pada Pemodelan Infeksi Wabah COVID-19 di Indonesia melalui Modifikasi Persamaan Differensial Bernoulli

[11] M J Keeling \& P Rohani. Modeling Infectious Diseases in Humans and Animals. New Jersey: Princeton Uni versity Press, 2007.

[12] D F Yuan, L Y Ying \& C Z Dong, Research Progress on Epidemic Early Warning Model. Zhejiang Preventive Medicine, (08):20-24+27, 2012.

[13] F Zhang, L Li, H Y. Xuan Overview of infectious disease transmission models. Theory and Practice of Systems Engineering, 31(9):17361744, 2011.

[14] M Lipsitch, L Finelli, RT Heffernan, GM Leung, SC Redd, Improving the evidence base for decision making during a pandemic: the example of 2009 inuenza A/H1N1. Biosecurity and bioterrorism biodefense strategy practice and science 9: 89-115, 2011.

[15] S Eubank, H Guclu, VSA Kumar, M Marathe, A Srinivasan, et al. Modelling disease out breaks in realistic urban social networks. Nature 429: 180- 184, 2004.
[16] J Wallinga \& P Teunis, Different epidemic curves for severe acute respiratory syndrome reveal similar impacts of control measures. American Journal of Epidemiology 160: 509-516. 2004.

[17] C Barrett, $\mathrm{K}$ Bisset, J Leidig,A Marathe,M Marathe., Economic and social impact of inuenza mitigation strategies by demographic class. Epidemics 3: 19-31, 2011.

[18] https://www.kemkes.go.id/article/vie w/20031900002/Dashboard-DataKasus-COVID-19-di-Indonesia.html. diakses pada Tanggal 13 April 2020 pukul 06.30. 